\title{
Metonymy as the Means of Reflecting Oriental Culture in "Villette" by Charlotte Brontë
}

\author{
Jianwen $\operatorname{Liu}^{1, *}$ \\ ${ }^{1}$ School of Foreign Languages, Hunan University, Changsha, Hunan 410082, China \\ *Corresponding author. Email: liu_jianwen@hnu.edu.cn
}

\begin{abstract}
Metonymy is of significance to the creation of literary works, and it is regarded as the symbol of realism. Although seen as the peak of her realistic literary career, Charlotte Brontë's Villette receives much less attention in the academic field. Among the few research works on Villette, the focus is on the traditional literary topics, such as feminism, and none of them touches orientalism. From the perspective of cognitive metonymy, by analyzing the two oriental images of opium and shawl, the authors argue that metonymy plays a vital role in helping Charlotte Brontë to express her opinions about India and China, as well as her cultural bias on those oriental countries. This kind of cultural bias is a typical indicator of orientalism.
\end{abstract}

Keywords: Metonymy, Orientalism, Villette.

\section{INTRODUCTION}

As the last novel written before Charlotte Brontë's early death, Villette 1 is comparable to Jane Eyre and her other works in writing techniques as well as the content. However, Villette receives much less attention in the academic field, ${ }^{2}$ which can be seen from the quantities and qualities of both versions of translation and related research literature on them. Besides, among the relative less literature, the focus of research is mainly on some traditional topics, such as, feminism, Lucy's attitude towards love, the narrating technique, or the comparison and contrast between Villette and other works by Charlotte Brontë, especially Jane Eyre. By far, orientalism has been rarely touched. This is surprising, considering the elegantly described oriental images of opium and shawl in this novel. Employing metonymy from Cognitive Linguistics

1. We adopt the Broadview Edition of Villette: Charlotte Brontë, Villette, edited by Kate Lawson (Ontario: Broadview Press Ltd., 2006. Broadview Press is an independent international publishing house famous for "bringing together texts long regarded as classics with valuable lesser-known works").

2. As for why Villette was well-written but has received much less attention, there are several reasons, like the pervasive use of French and Gothicized strangeness etc. At least, this is the case in China. as an analysing tool, we try to dig out the unexpressed but obvious orientalism in Villette.

\section{CONCEPTUAL METONYMY}

From the perspective of Cognitive Linguistics, metonymy is not only a rhetorical device, but also a basic cognitive tool based on the contiguity between two concepts or entities within one cognitive domain. The basic function of metonymy lies in a stand for relation between the two conceptual entities involved - one (vehicle or source domain) providing mental access to the other (tenor or target domain).[1] Taking the domain of restaurant for example: If a waitress said: Table No. 5 fled with paying, without difficulty at all, we know by "Table No. 5" she means "the customer" who was just sitting by that table. This relation is referential in nature, which encompasses the traditional part-whole relation (e.g., Our department needs some hands, in which hand is used to stand for person) and whole-part relation (e.g., His car was broken, in which car is usually used to stand for engine). Although there seems to be no set rules for this referentiality as how it applies in all cases, it is by no means arbitrary. Instead, it is strongly motivated by our life experiences,[2] and gradually entrenched into and reified by everyday language. 
From what we see above, people tend to employ a relatively more salient concept to refer to a less salient one in the same conceptual domain. During this process of metonymy, if one of the two concepts is highlighted, the other is inevitably veiled. Sometimes, via inviting more cognitive effort of readers in finding out and reasoning about the veiled entity, the writer is expecting to invoke some deep thought about an intended topic (closely related to the target). This revealing via veiling function of metonymy is of great importance in creative writing. What is of equal importance about metonymy is the evaluation function. Compared with the equivalent literal expressions, metonymic ones are assigned with relatively stronger emotional coloring, which reveals the writer's attitudes or views about the topic. For instance, different body parts, like head, hand and face, can be used metonymically to refer to a whole person but with subtle differences. In Chinese, a "high hand" refers to a skilled and usually respectable person, while a "dog's leg" refers to kind of scumbag.

\section{METONYMY AND LITERARY CREATION AND INTERPRETATION}

The most prominent feature of linguisticsliterature interdisciplinary studies is to employ linguistic theories to analyse literary works, which is of great methodological and epistemological significance.[3] Conceptual metonymy is useful in recognising how symbols work in the analysis of literary works, and also helpful in recognising the formal differences in terms of styles and schools. [4] Based on his intense analysis of a lot of literary works, linguist, literary theorist and formalist aesthetician Roman Jakobson pointed out that metonymy is of great importance to literary creation, and he regarded it as a symbol of the school of realism, whose trend is predetermined by metonymy.[5]

\section{ORIENTALISM}

"Orientalism" is a reconstruction about the East by European Countries (especially the Britain and France). Although it was put forward by Edward Said in 1978, the concept had been developed from almost two centuries earlier, when colonialism began to grow, and when colonial system of imperialism came into being. Therefore, it reflects the social values and ideology, as well as the cultural practice of the oriental in the eyes of the occidental. Consequently, this reconstruction is labeled as "social stagnation, cultural lag, arbitrary rule and ignorant people, etc.". The oriental became the Other in the eyes of the occidental.[6][7]

Although Villette was written almost one and a half century earlier than orientalism was put forward, ${ }^{3}$ it is worthwhile to interpret the orientalism in this realist novel with metonymy, which is seen as a symbol of the school of realism.

\section{ORIENTALISM IN VILLETTE FROM THE PERSPECTIVE OF METONYMY}

As discussed above, metonymy is based on contiguity between two concepts within the same cognitive domain, where one concept provides mental access to the other. People prefer to employ a salient concept to refer to or activate a less salient one (but not unimportant). With the impulse of striving for innovation in their works, while for the sake of their own safety (e.g., free from political persecutions) or reputation (e.g., free from being regarded as being racial discriminative or chauvinistic) etc., more often than not writers (Charlotte Brontë is no exception) adopt kind of roundabout way in describing the desired target and thereby expressing their attitude and opinions. That's where and how metonymy works for literary creation, especially for realist writers.

We argue that technically Charlotte Brontë employed metonymy in composing Villette, and as far as the content is concerned, she would most probably write directly or allude to the oriental, e.g. the easterners or their life styles, their values and the like. Here are the evidences: Charlotte Brontë lived in a period when the oriental literature was popular[8] and when Britain was developing its colonialism; she was a prominent figure in the literary circle at that time; as a public figure, she was aware of what was going on in Britain and its relationship with other countries (e.g., the colonial India, and the First Opium War with China (Qing dynasty at that time)). All considered, the images appeared in Villette, as well as her attitude towards them would definitely express her orientalism. Now we focus on how this effect is achieved with the metonymic allusion to the images of "shawl" and "opium".

3. Maybe this time difference explains (partly) why Villette has not been discussed from the perspective of orientalism. 


\section{6. "SHAWL" AND INDIA ${ }^{4}$}

"Shawl" appeared 45 times in Villette, one of which is used to introduce Madame Beck, at the end of Chapter 38 "Cloud"[9]: And there, in an Indian shawl and a pale-green crape bonnet there, fresh, portly, blithe, and pleasant - there stood Madame Beck. ${ }^{5}$ In this single sentence, Charlotte Brontë employed three syntactic means to emphasize the shawl worn by Madame Beck: repetition, independent construction and inverted structure. ${ }^{6}$

Until today, once Indians are mentioned, many would still think of "shawl" as their typical dress (for Indian women). Gradually, "shawl" has become a symbol of the Indians and the Indian clothing. Therefore, a kind of typical dress (of high salience) is used to refer to or allude to a particular people wearing it - here is metonymy. Considering the relation between the Britain and India, as well as that between Lucy and Madame Beck, we can safely assume that the shawl worn by Madame Beck was well designed - this technique had been used in describing Blanche Ingram in Jane Eyre. For the women she disliked or looked down upon, Charlotte Brontë would have them put on a shawl, thereby depriving them of the "Englishness",[10] and then successfully and naturally portraying them as the Other. The achievement of this effect heavily depends on the mechanism of metonymy, to be exact, on the referentiality between the "shawl" and the Indians within the domain of "Indians shawl". This domain consists of mainly two subdomains: shawl and Indians. Based on the nature of metonymy discussed above and the relevant description about shawl in Villette, "Indians shawl" can stand for "Indians" (whole for part, conceptually), and "shawl" for "Indians" (part for part, conceptually). The referentiality between them can be shown in the following "Figure 1":

4. We make no exact difference between country (India and China) and its people (Indians and Chinese) in this article, and we believe this doesn't influence the interpretation of Charlotte Brontë's use of "shawl" or "opium" in Villette.

5. Bold is not original, and it is used here for emphasis.

6. The word "there" is used for three times, and it is deictic (not existential), directing readers' attention to the Madame Beck.

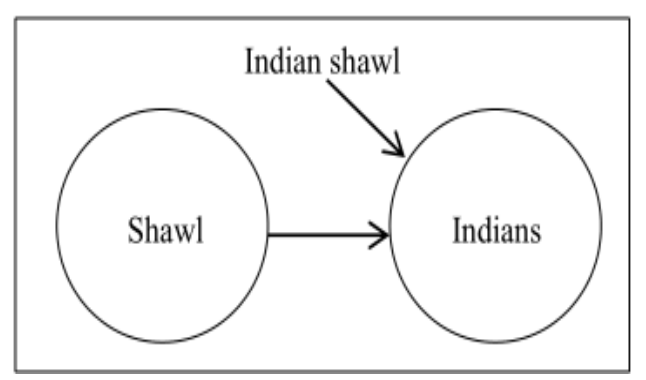

Figure 1 Referentiality within the domain of "Indians shawl".

\section{7. "OPIUM" AND CHINA (QING DYNASTY)}

Let's first look at several paragraphs in Chapter 38 in Villette:[11]

I was consumed with thirst - I drank eagerly; the beverage was sweet, but I tasted a drug.

"Madame says it will make you sleep, chouchou," said Goton, as she received back the emptied cup.

Ah! the sedative had been administered. In fact, they had given me a strong opiate. I was to be held quiet for one night.

[......]

The drug wrought. I know not whether Madame had over-charged or under-charged the dose; its result was not that she intended. Instead of stupor, came excitement.

Here, Charlotte Brontë used "sedative," "a strong opiate," "drug" and "dose," all of which refer to "opium." Besides these words, in other parts of the novel, the author carefully chose "poison," "opiate," "palliative," "narcotic," "cordial," "draught," and "drops" etc. All those words of different lexical forms (see "Figure 2".) are employed to express, from different aspects and with different details, Lucy's attitude towards characters like Madame Beck; considering the first Opium War (1839-42) fought between China (then Qing dynasty) and Britain as a macro-context, ${ }^{7}$ we can safely assume that Charlotte Brontë was indirectly expressing her attitude towards China (Chinese).

7. Almost all Charlotte Brontë's works, from Jane Eyre (1847) to Villette (1853), were written between two Opium Wars. 


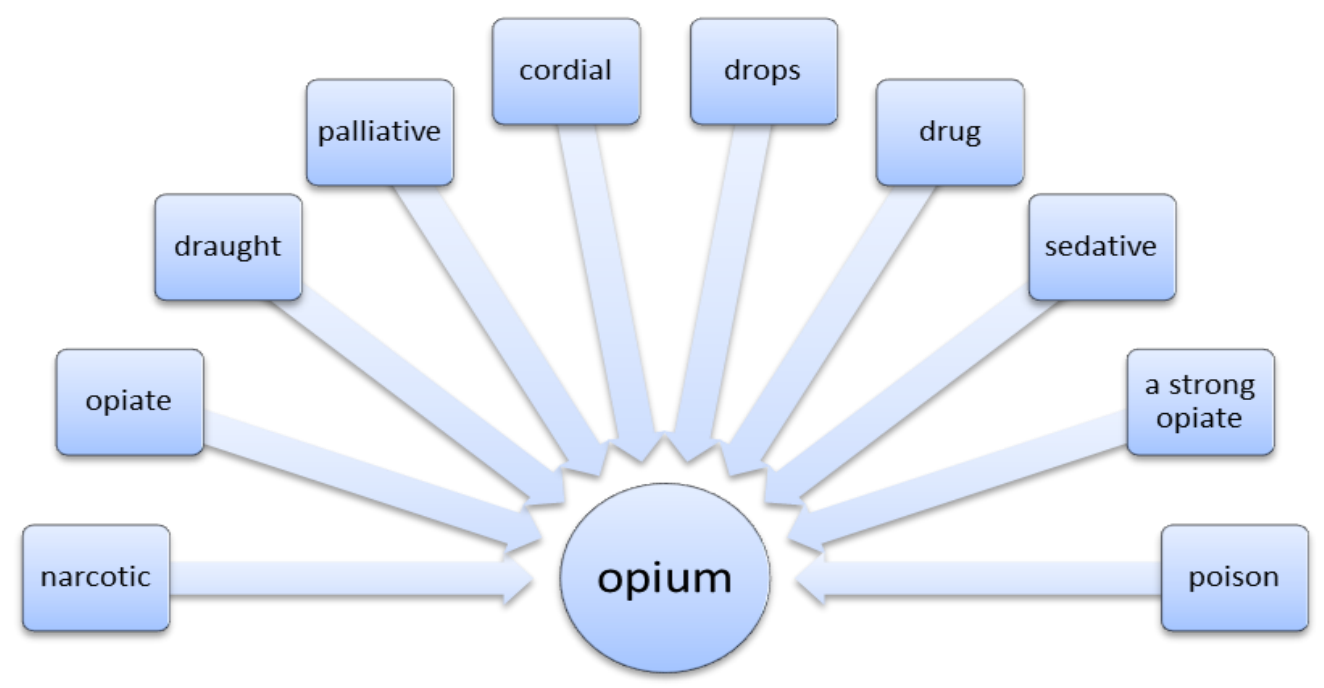

Figure 2 Different lexical forms for "opium" in Villette.

Once opium is mentioned, it always reminds people of drugs, the two Opium Wars, India (where opium was grown and produced), China (then Qing dynasty), the opium combustion in Humen, ${ }^{8}$ those skinny opium addicts lying in bed, as well as medicine containing opium etc. Those concepts form an opium-related domain:

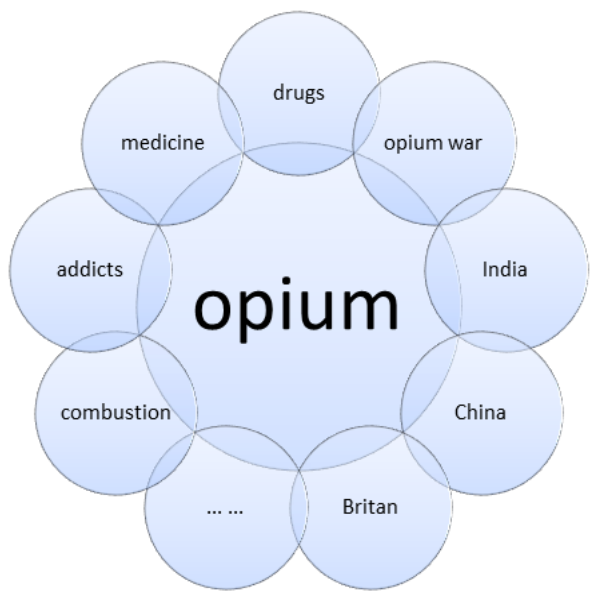

Figure 3 Opium-related domain.

The concepts in "Figure 3" are interrelated via "opium", resulting in a cognitive domain (no boundary means it's an open one). Different concepts have different associative meanings, such

8. Humen is a town in Canton Province in southern China. In June 1839, a large amount of opium was destroyed there. The official in charge of this event was the imperial envoy Lin Zexu, who led his civil and military officials and invited some foreign ambassadors to Canton there as witnesses. Qing Empire wanted to show her determination of destroying the harmful opium and ending the opium trade. Understandably, this event became the direct cause of the First Opium War between Britain and China. as poisonous, country-wrecking and people-ruining (as drugs), pain-relieving (as medicine or palliative), etc. Of course, this association is by no means arbitrary, and it is constrained by rich and wellknown and widely shared background knowledge, especially the macro-context of the First Opium War related historical knowledge; those information, reified by different forms of opium (as in "Figure 2") or opium-related association (as in "Figure 3"), provide metonymically solid foundation for an appropriate interpretation of Villette and a smooth communication between the author and her readers. With the aid of the macrocontext, referentiality between those contiguous concepts can be realized. At the same time, with the help of metonymy's evaluation function, Charlotte Brontë expressed her attitude towards China; similarly, revealing via veiling function of metonymy is employed skillfully to express indirectly her views about the First Opium War. We'll discuss about her attitude and views in the following part.

To begin with, we have to think about the following questions: From Jane Eyre (1847) to Villette (1853), almost all her works were written between two Opium Wars, but why Charlotte Brontë, as a public figure who had been aware of current affairs at that time never mentioned any event related to the war in her novels? In Villette alone, Charlotte Brontë chose at least 10 different lexical forms to refer to "opium," but why she never mentioned directly the "opium" even once, let alone the First Opium War?

For those questions, there are some literary critics think that Charlotte Brontë was intentionally 
avoiding mentioning the First Opium War and therefore adopted a roundabout way in her writing.[12] We have to ask two more questions: Why did she try to avoid mentioning the First Opium War? How did she make it?

For the first question, some scholars assume that by describing opium as "catholicon" or "magic potion" and by eulogizing the Crusades, Charlotte Brontë managed to take part in the then fierce debate over Britain's opium trade with China and the opium war against China; furthermore, her doing so provides moral and aesthetic support for and legalization of the opium trade with China and the opium war against China, which had been opposed by the anti-opium alliance, as well as the anti-war alliance represented by William E. Gladstone. Legalization of Britain's action is one side of the coin, and the other side is the uglification of China (Qing Dynasty).[13]

We totally agree with Cheng and other scholars' analysis, but the second question is even more important: How did Charlotte Brontë, by describing "opium" in a roundabout way, attain her goal of writing as analysed in answering the first question? Writers and many cognitive linguists usually fail to notice two functions of metonymy discussed above: evaluation and revealing via veiling. The employment of those different lexical forms of opium provide skillfully enough room for metonymic referentiality; those words all allude to opium, and metonymically refer to the opium trade with China and the opium war against China. Naturally, they helped Charlotte Brontë to express her attitude towards the trade and the war. As is shown in "Figure 2", due to the contiguous relationship between those words, "opium" in the center (and its function) is profiled, thereby leaving enough room for imagination for readers, and more importantly, metonymically describing the "disgraceful" role in played by Chinese the trade and the war with Britain.

\section{CONCLUSION}

Since the beginning of $20^{\text {th }}$ century, a linguistic turn has been exerting its influence in the circle of humanities. As for literary studies, it has been innovating the paradigm of literary research. ${ }^{9}$ On

9. An example in case is the publication of Saussure's Course in General Linguistics, which was compiled by Ferdinand de Saussure's students Charles Bally and Albert Sechehaye from notes on lectures given by him at the University of Geneva between 1906 and 1911; the book was published after one hand (inwardly), the linguistic turn has helped to bring the focus of literary studies back to the text per se; on the other hand (outwardly), it has facilitated the expansion of literary studies to embrace other disciplines, thereby enabling the permeation of literary studies in the humanities on a higher level.[14] Cognitive metonymic analysis of literary works is a development in this trend.

Metonymy, which is thought of as the symbol of realism by Roman Jakobson,[15] is of great significance to the creation and interpretation of literary works. Although seen as the peak of her realistic literary career, Charlotte Brontë's last novel written before her death - Villette, compared with her other novels like Jane Eyre, receives relatively much less attention in the academic field. Among the few research works on Villette, the focus is on the traditional literary topics, such as feminism, and very few of them touch orientalism. This is a kind of pity, because there are several important oriental images appeared repeatedly and they must be employed for particular purposes. From the perspective of cognitive metonymy, by analyzing the two oriental images of opium and shawl, ${ }^{10}$ we argue that metonymy plays a vital role in aiding Charlotte Brontë express her opinions on India and China, as well as her cultural bias on those oriental countries. This kind of cultural bias is a typical indicator of orientalism.

\section{AUTHORS' CONTRIBUTIONS}

This paper is independently completed by Jianwen Liu.

\section{REFERENCES}

[1] Zoltán Kövecses, Metaphor (Oxford: Oxford University Press, 2002), p. 145.

[2] Shen Jiaxuan, 'A metonymic model of transferred designation of de-construction in Mandarin Chinese', Contemporary Linguistics, 1 (1999), 4.

[3] Xiong Muqing, 'The meanings and significance of interfaces and the interface properties of cognitive poetics', Foreign Language and Literature, 5 (2013), 11.

Saussure's death in 1916 and it influenced some famous literary critics including Roman Jakobson.

10. Of course, there are other images besides shawl and opium discussed in the present article, for instance, Great Wall and turban. 
[4] Liu Tao, 'The interactional model of metaphor and metonymy', Journalism and Mass Communication, 12 (2018), 36.

[5] Roman Jakobson, 'The metaphoric and metonymic poles', Fundamentals of Language (Berlin: Mouton, 1956), pp. 76-77.

[6] Jiang Yonglin, 'Edward Said's Orientalism and its contemporary value', Historiography Quarterly, 2 (2019), 4.

[7] Edward Said, Orientalism (New York: Vintage, 1978).

[8] Cheng Wei, 'Charlotte Brontë: Opium, 'East' and the 1851 Great Exhibition', Foreign Literature Review, 4 (2015), 82.

[9] Charlotte Brontë, Villette, edited by Kate Lawson (Ontario: Broadview Press Ltd., 2006), p. 531.

[10] Cheng Wei, 'Charlotte Brontë: Opium, 'East' and the 1851 Great Exhibition', Foreign Literature Review, 4 (2015), 106.

[11] Charlotte Brontë, Villette, edited by Kate Lawson (Ontario: Broadview Press Ltd., 2006), p. 522.

[12] Cheng Wei, 'Charlotte Brontë: Opium, 'East' and the 1851 Great Exhibition', Foreign Literature Review, 4 (2015), 64.

[13] Cheng Wei, 'Charlotte Brontë: Opium, 'East' and the 1851 Great Exhibition', Foreign Literature Review, 4 (2015), 84.

[14] Wang Zhenglong, 'Linguistic turn and literature studies,' Journal of Hubei University (Philosophy and Social Science), 4 (2019), 31.

[15] Jiang Fei, 'Metaphor and Metonymy: Two Basic Models of Roman Jakobson's Cultural Semiotics,' Russian Literature and Art, 2 (2016), 85. 